\begin{tabular}{|l|l|l|}
\hline \multicolumn{2}{|c|}{ PublisherInfo } \\
\hline \hline PublisherName & $:$ & BioMed Central \\
\hline \hline PublisherLocation & $:$ & London \\
\hline \hline PublisherImprintName & $:$ & BioMed Central \\
\hline \hline
\end{tabular}

\title{
Methylation and imprinting
}

\begin{tabular}{|l|l|l||}
\hline \multicolumn{2}{|c|}{ ArticleInfo } \\
\hline \hline ArticleID & $:$ & 4581 \\
\hline \hline ArticleDOI & $:$ & $10.1186 /$ gb-spotlight-20020916-02 \\
\hline \hline ArticleCitationID & $:$ & spotlight-20020916-02 \\
\hline \hline ArticleSequenceNumber & $:$ & 247 \\
\hline \hline ArticleCategory & $:$ & Research news \\
\hline ArticleFirstPage & $:$ & 1 \\
\hline \hline ArticleLastPage & $:$ & 2 \\
\hline \hline & & RegistrationDate : 2002-9-16 \\
\hline ArticleHistory & $:$ & OnlineDate \\
\hline \hline ArticleCopyright & $:$ & BioMed Central Ltd2002-16 \\
\hline \hline ArticleGrants & $:$ & \\
\hline \hline ArticleContext & $:$ & 130593311 \\
\hline \hline
\end{tabular}




\section{Jonathan B Weitzman}

Email: jonathanweitzman@hotmail.com

A third of human patients with Beckwith-Wiedemann syndrome (BWS) have lost maternal-specific methylation of the $K v D M R I$ (differential methylated region) locus, a putative imprinting control region found within the KCNQ1 gene. In an Advanced Online Publication in Nature Genetics, Fitzpatrick et al. provide clear evidence linking KvDMRI to imprinted gene expression (Nature Genetics, 9 September 2002, DOI:10.1038/ng988). They generated mice in which KvDMRl was deleted by gene-targeted homologous recombination. Paternal transmission of the deletion resulted in deregulated imprinting of the genomic locus and reactivation of genes both distal and proximal to KvDMR1. Paternal inheritance was also associated with reduced weight. Fitzpatrick et al. speculate that elevated levels of maternally expressed genes (such as $C d k n 1 c$, encoding a cyclin-dependent kinase inhibitor) account for the growth defect.

\section{References}

1. Epigenotype-phenotype correlations in Beckwith-Wiedemann syndrome.

2. Nature Genetics, [http://www.nature.com/ng/] 